\title{
PENETAPAN KADAR FENOLAT TOTAL DAN FLAVONOID TOTAL EKSTRAK ETANOL DAUN, KULIT BATANG DAN KULIT BUAH KASTURI (Mangifera casturi )
}

\author{
Lia Marliani*, Anni Naimah, Asep Roni \\ Sekolah Tinggi Farmasi Bandung \\ Jl. Soekarno Hatta No. 754 Bandung \\ *Email: l.marliani.pharm@gmail.com
}

\begin{abstract}
ABSTRAK
Kasturi (Mangifera casturi) merupakan jenis mangga khas Kalimantan Selatan yang banyak dikonsumsi karena rasanya yang manis. Kandungan metabolit aktif yang terkandung dalam tanaman, seperti golongan fenolat dan flavonoid, perlu diketahui sebagai bahan kajian ilmiah pengembangan obat. Penelitian ini bertujuan menetapkan kadar fenol total dan flavonoid total dari ekstrak etanol daun, kulit batang,dan kulit buah kasturi. Ekstraksi dilakukan dengan metode maserasi menggunakan pelarut etanol 96\%. Pengujian kandungan senyawa fenolat dan flavonoid secara kualitatif dilakukan menggunakan metode kromatografi lapis tipis (KLT) dengan fase diam silika gel $\mathrm{GF}_{254}$ dan penampak bercak spesifik $\mathrm{FeCl}_{3} 10 \%$ untuk senyawa fenolat, $\mathrm{AlCl}_{3} 5 \%$ dan sitroborat untuk senyawa flavonoid. Kadar fenolat total ditetapkan menggunakan reagen Folin Ciocalteu dan kadar flavonoid total menggunakan metode Ordon. Hasil penentuan kadar fenolat total pada daun, kulit batang, dan kulit buah berturut-turut adalah 18,44 $\pm 0,12 ; 16 \pm 0,12$; dan 18,37 $\pm 1,2 \%$. Kadar flavonoid total pada daun, kulit batang dan kulit buah berturut-turut adalah $9,27 \pm 0,14 ; 7,92 \pm 0,029$; dan 2,098 $\pm 0,0026 \%$. Hasil penelitian menunjukkan bahwa kandungan fenolat dan flavonoid tertinggi terdapat pada daun sedangkan kandungan fenolat total terendah terdapat pada kulit batang dan kandungan flavonoid total terendah terdapat pada kulit buah.
\end{abstract}

Kata Kunci : Kasturi (Mangifera casturi), fenolat total, flavonoid total, , Folin Ciocalteu

\begin{abstract}
Kasturi (Mangifera casturi) are one type of mango from South Kalimantan that has comsumed becaused it tastes sweet. The content of active metabolites that contained in the plant such as phenolic and flavonoid, has to know as scientific study of drug development. The aims of this study was to determine total phenolic and flavonoid of ethanol extract from Kasturi (Mangifera casturi) leaves, cortex, and peel. Extraction was done by maceration method using ethanol $96 \%$ solvent. The qualitative assay of phenolic and flavonoid content was done by Thin Layer Chromatography (TLC) using silica gel $\mathrm{GF}_{254}$ and $\mathrm{FeCl}_{3} 10 \%$ as spray reagent for phenolic, $\mathrm{AlCl}_{3} 5 \%$ and sitroborat for flavonoid. Total phenolic content was determined using Folin Ciocalteu reagent and flavonoid content by Ordon method. The total phenolic content determination showed that total phenolic content of leaves, cortex, and peel respectively are $18.44 \pm 0.12 \%$; $16 \pm 0.12 \%$; dan $18.37 \pm 1.2 \%$. Total flavonoid content of leaves, cortex, and peel respectively are $9.27 \pm 0.14 \% ; 7.92 \pm$ $0.029 \%$; dan $2.098 \pm 0.0026 \%$. The results showed that the highest content of phenolics
\end{abstract}


and flavonoids present in the leaves while the total phenolic content was lowest for the cortex and total flavonoid content was lowest for the peel.

Keywords : Kasturi (Mangifera casturi), total phenolic, total flavonoid, Folin Ciocalteu

\section{PENDAHULUAN}

Telaah fitokimia pada berbagai tanaman banyak dilakukan untuk mengetahui kandungan senyawa aktif baik sebagai dasar ilmiah penggunaan obat tradisional maupun digunakan dalam pengembangan obat baru. Sebagian besar komponen senyawa aktif pada bahan alam merupakan senyawa metabolit sekunder seperti golongan alkaloid, terpenoid, fenolat, flavonoid, dan sebagainya. Golongan senyawa yang ditelaah diantaranya golongan senyawa fenolat dan flavonoid.

Senyawa fenolat memiliki beberapa aktivitas farmakologi, diantaranya adalah antioksidan sebagai pereduksi, penangkap radikal bebas, pengkhelat logam, peredam terbentuknya oksigen singlet serta pendonor elektron $(1,2)$. Flavonoid merupakan salah satu golongan senyawa fenolat yang terbesar. Flavonoid telah diteliti memiliki potensi yang besar untuk melawan penyakit yang disebabkan oleh radikal bebas (3).

Golongan senyawa fenolat dan flavonoid tersebar luas di berbagai spesies tumbuhan. Salah satunya adalah Genus Mangifera, family Anarcardiaceae. Berdasarkan teori kemotaksonomi, tumbuhan yang termasuk kedalam genus yang sama pada umumnya memiliki kandungan senyawa kimia yang hampir sama. Salah satu anggota genus ini adalah mangga (Mangifera indica L). Kulit batang mangga (Mangifera indica L) positif mengandung alkaloid (4). Penelitian lain menyebutkan bahwa biji, daun dan batang Mangga mengandung flavonoid dan terpenoid, sedangkan daun dan kulit batang juga mengandung saponin serta biji dan kulit batangnya mengandung tanin (5). Buah Mangga mengandung Triterpenoid Lupeol (6). Jenis Mangifera lain yang telah diteliti adalah kuweni (M.odorata). Sugai et al., 2006 (7) dalam penelitiannya menyebutkan akar Mangifera odorata mengandung senyawa taraxasterol.

Beberapa anggota genus Mangifera diketahui memiliki aktivitas antioksidan. Ekstrak metanol dari kulit batang (kulit luar, gubal, dan teras) tiga spesies mangifera, yaitu mangga (Mangifera indica L.), pakel (Mangifera foetida Lour), dan kweni (Mangifera odorata Griff.) diketahui memiliki aktivitas antioksidan. Ekstrak metanol dari gubal pakel serta kulit kweni secara nyata memberikan aktivitas antioksidan tertinggi jika dibandingkan dengan antioksidan standar (asam galat dan katekin) dengan nilai IC50 sekitar 3-10 ppm (8). Penelitian pada ekstrak etanol daun mangga bacang (Mangifera foetida L.) dapat menghambat pertumbuhan bakteri Escherichia coli (9).

Anggota genus Mangifera yang endemik di Kalimantan salah satunya adalah Kasturi (Mangifera casturi). Akar dan batang kasturi mempunyai komponen kimia yakni saponin dan tanin (10). Senyawa saponin pada Kulit batang kasturi berperan baik dalam menghambat pertumbuhan bakteri S.aureus dan E.coli (5). Batang tumbuhan kasturi juga mengandung senyawa triterpenoid $(11,12)$. Kandungan Flavonoid pada Ekstrak air buah mangga kasturi lebih besar dibandingkan daun kelakai, batang garunggang, ataupun akar pasak bumi (13) Senyawa yang teridenfikasi dari fraksi n-heksan buah kasturi merupakan senyawa terpenoid yaitu lupeol (14).

Penelitian sebelumnya menunjukkan bahwa ekstrak metanol buah mangga kasturi berpotensi sebagai anti inflamasi melalui penghambatan migrasi leukosit (15). Fraksi etil asetat daun kasturi menunjukkan efek analgetik (16).

Kasturi menarik diteliti karena meskipun sebagai identitas flora Kalimantan Selatan keberadaannya saat ini terancam punah. Tanaman kasturi belum dibudidayakan karena 
umur mulai berbuah sangat panjang. Pohonnya sangat besar dan tinggi sehingga orang sulit mengambil buahnya dan hanya menunggu buah yang jatuh. Selama ini, masyarakat hanya memanfaatkan buahnya untuk dikonsumsi karena rasa buahnya yang manis dan aromanya yang khas. Sedangkan bagian tumbuhan lainnya seperti batang, akar, daun, biji dan kulit buah belum dimanfaatkan dengan maksimal.

Berdasarkan hal tersebut, penelitian ini dilakukan untuk menelaah kandungan senyawa, khususnya senyawa fenolat dan flavonoid dari tiga bagian tumbuhan kasturi yaitu daun, kulit batang dan kulit buah.

\section{METODE PENELITIAN}

\section{Bahan}

Bahan yang digunakan pada penelitian ini adalah daun, kulit batang dan kulit buah kasturi (Mangifera casturi) yang berasal dari Kabupaten Barito Kuala, Provinsi Kalimantan Selatan. Bahan yang telah disortasi dan dicuci bersih kemudaian dikeringkan. Pengeringan bahan dilakukan dengan menggunakan sinar matahari tidak langsung.

\section{Ekstraksi}

Simplisia kulit batang, daun dan kulit buah kasturi masing-masing dimaserasi menggunakan pelarut etanol 96\% selama 3 x @24 jam. Ekstrak kemudian disaring dan diuapkan menggunakan rotary evaporator agar diperoleh ekstrak kental.

\section{Uji Kualitatif Ekstrak}

Untuk mengetahui adanya senyawa fenol dilakukan pemantauan atau uji kualitatif ekstrak dengan kromatografi lapis tipis menggunakan pengembang yang sesuai dengan fase diam silica gel GF254. Untuk mengetahui adanya senyawa fenol digunakan penampak bercak $\mathrm{FeCl}_{3} 10 \%$. Untuk mengetahui adanya flavonoid dilakukan pemantauan ekstrak dengan KLT menggunakan pengembang yang sesuai dengan silica gel GF254. Untuk mengetahui adanya senyawa flavonoid digunakan penampak bercak $\mathrm{AlCl}_{3} 5 \%$ dan Sitroborat.

\section{Penetapan Kadar Fenolat Total}

Penetapan kadar fenolat total pada ekstrak menggunakan reagen Folin-Ciocalteu. Larutan induk ekstrak dibuat dengan cara melarutkan ekstrak dengan metanol air (1:1) kemudian disaring lalu ditambahkan hingga tanda batas. $0,5 \mathrm{~mL}$ ekstrak sampel ditambahkan $5 \mathrm{~mL}$ Folin-Ciocalteu (sebelumnya diencerkan dengan air 1:10) inkubasi 5 menit kemudian ditambahkan $4 \mathrm{~mL}$ natrium karbonat $1 \mathrm{M}$ dan diinkubasi 15 menit. Standar yang digunakan adalah asam galat. Standar mengalami perlakuan yang sama dengan ekstrak. Ekstrak dan standar diukur pada panjang gelombang $765 \mathrm{~nm}$. Kadar fenolat total dihitung sebagai asam galat dari kurva kalibrasi yang didapat (17).

\section{Penetapan Kadar Flavonoid}

Penetapan kadar flavonoid total ditetapkan dengan menggunakan metode Ordon, yang menggunakan prinsip kolorimetri dengan menggunakan aluminium klorida sebagai pembentuk kompleks berwarna flavonoid.

Sampel dan standar dilarutkan dalam metanol ditambahkan $\mathrm{AlCl}_{3} 2 \%$ dalam etanol $96 \%$ dengan perbandingan 1:1 dan diinkubasi selama satu jam, absorbansi diukur pada panjang gelombang $420 \mathrm{~nm}$ menggunakan spektrofotometri UV-Vis, kadar flavonoid dihitung terhadap kurva kalibrasi dengan kuersetin sebagai pembanding (18). 


\section{HASIL DAN PEMBAHASAN}

Hasil pemantauan pola kromatogram ekstrak (Gambar 1) menunjukkan ketiga ekstrak mengandung senyawa fenolat (bercak hitam dengan penampak bercak $\mathrm{FeCl}_{3}$ ) dan flavonoid (penampak bercak $\mathrm{AlCl} 35 \%$ dan Sitroborat).

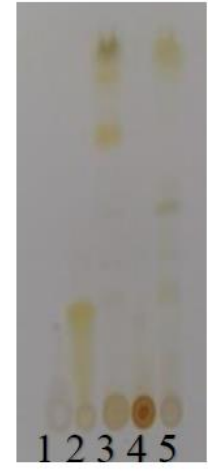

(a)

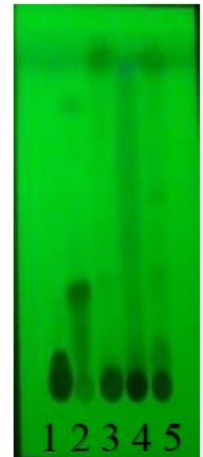

(b)

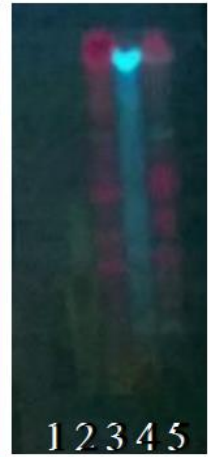

(c)

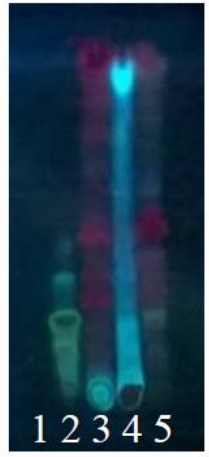

(d)

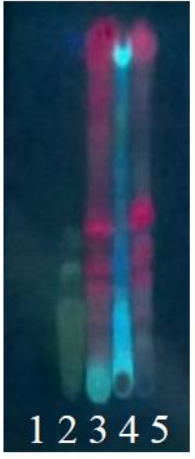

(e)

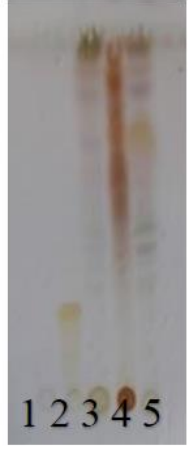

(f)

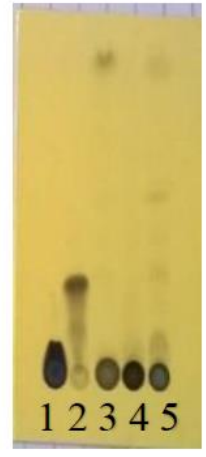

(g)

Gambar 1 : Pola Kromatogram KLT (1) Asam Galat, (2) Kuersetin, (3) Daun, (4) Kulit Batang dan (5) Kulit Buah Kasturi, dengan fase gerak semi polar Kloroform Metanol (7:1) secara : (a) visual, menggunakan penampak bercak : (b) lampu UV $\lambda 254 \mathrm{~nm}$, (c) lampu UV $\lambda 365 \mathrm{~nm}$, (d) AlCl3 5\%, (e) Sitroborat, (f) $\mathrm{H} 2 \mathrm{SO} 410 \%$, dan (g) $\mathrm{FeCl} 3$ 10\%.

Kandungan senyawa fenolat dan flavonoid tersebut ditetapkan secara kuantitatif secara spektrofotometri UV-Vis dengan menggunakan asam galat sebagai standar senyawa fenolat dan kuersetin sebagai standar senyawa flavonoid. Kurva standar asam galat dan kuersetin dapat dilihat pada gambar 2.

Kurva Standar Asam Galat

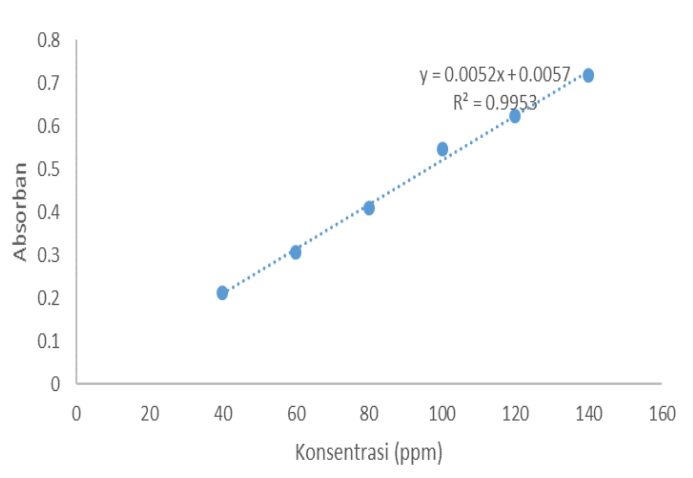

Kurva Standar Kuersetin

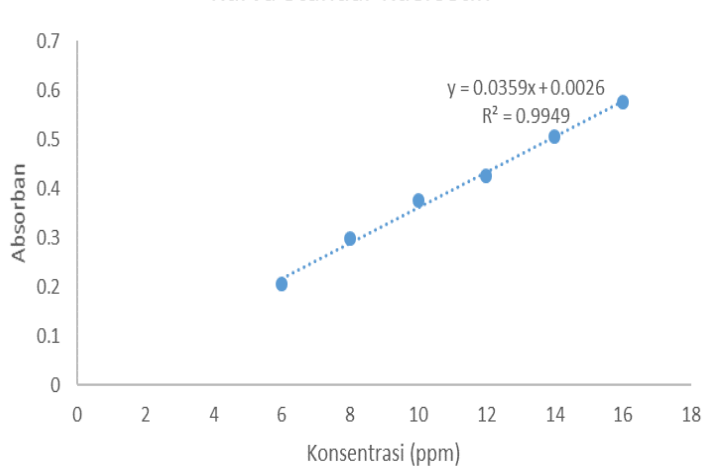

Gambar 2 : Kurva standar asam galat dan kuersetin

Hasil pengujian pada ekstrak menunjukkan kandungan senyawa fenol total pada ekstrak etanol daun kasturi memiliki nilai lebih besar yaitu 18,43 $\pm 0,13 \%$ dibandingkan kulit buah kasturi sebesar 18,38 $\pm 1,2 \%$ dan kulit batang kasturi sebesar $16 \pm 0,87 \%$ (Tabel 1) 
Tabel 1 Kadar Fenolat Sampel

\begin{tabular}{|c|c|c|c|}
\hline Sampel & Konsentrasi (ppm) & Ekuivalen Asam galat (ppm) & Kadar fenolat total (\%) \\
\hline \multirow{4}{*}{ Daun } & \multirow{3}{*}{500} & 92,56 & 18,28 \\
\hline & & 91,40 & 18,51 \\
\hline & & 91,40 & 18,51 \\
\hline & \multirow{4}{*}{750} & Rata-rata & $18,43 \pm 0,13$ \\
\hline \multirow{4}{*}{$\begin{array}{l}\text { Kulit } \\
\text { batang }\end{array}$} & & 112,75 & 15 \\
\hline & & 122,94 & 16,4 \\
\hline & & 124,86 & 16,6 \\
\hline & & Rata-rata & $16 \pm 0,87$ \\
\hline \multirow{4}{*}{$\begin{array}{l}\text { Kulit } \\
\text { buah }\end{array}$} & \multirow{3}{*}{500} & 87,17 & 17,44 \\
\hline & & 89,67 & 17,92 \\
\hline & & 98,9 & 19,76 \\
\hline & \multicolumn{2}{|r|}{ Rata-rata } & $18,37 \pm 1,2$ \\
\hline
\end{tabular}

Hasil penetapan kadar flavonoid sampel menunjukkan kandungan ekstrak etanol daun kasturi memiliki kandungan senyawa flavonoid total paling tinggi yaitu sebesar 9,27 \pm 0,15\% dibandingkan dengan kulit batang kasturi yaitu 7,92 $\pm 0,029 \%$ dan kulit buah kasturi yang hanya memiliki kandungan senyawa flavonoid total sebesar 2,098 $\pm 0,0026 \%$ (Tabel 2).

Tabel 2 Kadar Flavonoid Sampel

\begin{tabular}{|c|c|c|c|}
\hline Sampel & Konsentrasi (ppm) & Ekuivalen kuersetin (ppm) & Kadar flavonoid total (\%) \\
\hline \multirow{4}{*}{ Daun } & \multirow{3}{*}{200} & 18,56 & 9,28 \\
\hline & & 18,76 & 9,38 \\
\hline & & 18,2 & 9,1 \\
\hline & & Rata-rata & $9,27 \pm 0,14$ \\
\hline \multirow{4}{*}{$\begin{array}{c}\text { Kulit } \\
\text { batang }\end{array}$} & \multirow{3}{*}{210} & 16,529 & 7,9 \\
\hline & & 16,529 & 7,9 \\
\hline & & 16,696 & 7,95 \\
\hline & \multicolumn{2}{|c|}{ Rata-rata } & $7,92 \pm 0,029$ \\
\hline \multirow{4}{*}{$\begin{array}{l}\text { Kulit } \\
\text { buah }\end{array}$} & \multirow{3}{*}{1000} & 21,01 & 2,1 \\
\hline & & 20,986 & 2,099 \\
\hline & & 20,96 & 2,095 \\
\hline & \multicolumn{2}{|r|}{ Rata-rata } & $2,098 \pm 0,0026$ \\
\hline
\end{tabular}

Perbandingan kandungan fenolat total dan flavonoid total dari ketiga bagian tanaman kasturi dapat dilihat pada tabel 3.

Tabel 3 Perbandingan Kadar Fenolat Total dan Flavonoid Total Kasturi

\begin{tabular}{ccc}
\hline Sampel & Kadar Fenol Total $(\%)$ & Kadar Flavonoid Total (\%) \\
\hline Daun & $18,44 \pm 0,12$ & $9,27 \pm 0,14$ \\
Kulit Batang & $16 \pm 0,87$ & $7,92 \pm 0,029$ \\
Kulit Buah & $18,37 \pm 1,2$ & $2,098 \pm 0,0026$ \\
\hline
\end{tabular}


Berdasarkan data pada Tabel 3 tersebut, diketahui bahwa ekstrak etanol daun kasturi memiliki kadar senyawa fenolat total tertinggi yaitu 18,44 \% dan kadar flavonoid total tertinggi sebesar 9,27\%. Sedangkan untuk kadar senyawa fenolat terendah dari ketiga bagian tanaman tersebut terdapat pada ekstrak etanol kulit batang kasturi yang hanya memiliki kadar senyawa fenolat total sebesar $16 \%$ dan untuk kadar senyawa flavonoid terendah terdapat pada ekstrak etanol kulit buah kasturi yaitu sebesar 2,098\%. Hal ini menunjukkan bahwa kandungan senyawa fenolat non flavonoid pada kulit buah lebih banyak dibandingkan dengan kulit kayu. Kandungan senyawa fenolat lain selain flavonoid pada kulit buah diantaranya adalah tanin dan quinon. Kedua senyawa tersebut terbukti positif terkandung dalam kulit buah ketika dilakukan skrining fitokimia baik terhadap ekstrak ataupun simplisia.

\section{KESIMPULAN}

Hasil penentuan kadar fenolat total pada daun, kulit batang, dan kulit buah berturut-turut adalah $18,44 \pm 0,12 ; 16 \pm 0,12$; dan $18,37 \pm 1,2 \%$. Kadar flavonoid total pada daun, kulit batang dan kulit buah berturut-turut adalah 9,27 $\pm 0,14 ; 7,92 \pm 0,029$; dan 2,098 \pm $0,0026 \%$. Kandungan fenolat dan flavonoid tertinggi terdapat pada daun sedangkan kandungan fenolat total terendah terdapat pada kulit batang dan kandungan flavonoid total terendah terdapat pada kulit buah

\section{DAFTAR PUSTAKA}

1. Leopoldini, M., Marino, T, Russo, N, Toscano, M. 2004. Antioxidant Properties of Phenolic Compounds: H-Atom versus Electron Transfer Mechanism. J. Phys. Chem. A. 108. 4916-4922

2. Karadeniz, F., Burdurlu, H.S., Koca, N., Soyer, Y. 2005. Antioxidant Activity of Selected Fruits and Vegetables Grown in Turkey. Turkey Journal Agric. For.. 29. 297303

3. Amic, D., Davidovic-Amic, D., Beslo, D. \& Trinajstic, N. 2003. Structure-Radical Scavenging activity Relationships of Flavonoids. Original Scientific Paper. Croatia Chemica Acta. Vol. 76 (I), 55-61

4. Aksara, R., Musa A., Alio L. 2013. Identifikasi Senyawa Alkaloid Dari Ekstrak Metanol Kulit Batang Mangga (Mangifera indica L). Jurnal Entropi.Vol. VIII. Nomor 1.

5. Rosyidah, K., Nurmuhaimina, S.., Komari, N., Astuti, M. 2010. Aktivitas Antibakteri Fraksi Saponin Dari Kulit Batang Tumbuhan Kasturi (Mangifera casturi). ALCHEMY, Vol.1. No. 2. 53-103

6. Tovar, B., Ibara, L., Garcia, H., \& M. Miguel. 2000. Some Compositional Changes In Kent Mango (Mangifera Indica) Slices During Storange. J. Appl. Hort., 2(1). 10-14

7. Sugai, A., And Tadini, C. 2006. Thermal Inactivation Of Mango (Mangifera Odorata.,Variety Palmer) Puree Peroxidase. International Symposium On Future Of Food Engineering 2006, Cigr Section Vi Warsaw, Poland.

8. Lukmandaru, G., Vembrianto, K., dan Gazidy, A. 2012. Aktivitas Antioksidan Ekstrak Metanol Kayu Mangifera indica L., Mangifera foetida Lour, dan Mangifera odorata Griff.. Jurnal Ilmu Kehutanan. Vol. VI No. 1. Fakultas Kehutanan, Universitas Gadjah Mada, Yogyakarta.

9. Nuryanto, A. 2014. Uji Aktivitas Antibakteri Ekstrak Etanol Daun Mangga Bacang ( Mangifera Foetida L) Terhadap Escherichia coli secara In Vitro. Naskah Publikasi Fakultas Kedokteran Universitas Tanjungpura. Pontianak

10. Aryani, D., Mustikasari, K. 2008. Studi Potensi Binjai (Mangifera caesia) dan Kasturi (Mangifera casturi) Sebagai Antidiabetes Melalui Skrining Fitokimia pada Akar dan Batang. Sains Terapan Kimia. Vol.2, No. 2. Hal : 64-73 
11. Rosyidah, K., Ninawati, \& Nurmasari, R. 2009. Isolasi Senyawa Terpenoid Dari Batang Tumbuhan Kasturi (Mangifera Casturi). Seminar Nasional Kimia. ISBN 978979-95845-9-5.

12. Prayitno, B. 2011. Isolasi, Identifikasi dan Uji Antioksidan Senyawa dari Fraksi M 17 Ekstrak Metilena Klorida Kulit batang Tumbuhan Kasturi (Mangifera casturi). Skripsi. Fakultas Matematika dan Ilmu Pengetahuan Alam Universitas Lambung Mangkurat Banjarbaru.

13. Suhartono, E., et al. 2012. Total Flavonoid and Antioxidant Activity of Some Selected Medicinal Plants in South Kalimantan of Indonesia. ACPBEE Proced. Singapore, pp. 235-239.

14. Sutomo, Wahyuno, S., Rianto, S., \& Setyowati, E.P. 2013. Isolation and Identification of Active Compound of n-hexane Fraction from Kasturi (Mangifera casturi Konsterm.) against Antioxidant and Immunomodulatory Activity. Journal of Biological Scinces 13 (7) : 596-604

15. Fakhrudin, N., Putri, P. S., Sutomo, Wahyuono, S. 2013. Antiinflamatory Activity of Methanolic Extract of Mangifera casturi in Thioglycollate-Induced Leukocyte Migration on Mice. Traditional Medicine Journal, 18(3). 151-156.

16. Yustisia R. 2012. Uji Efek Analgetik Fraksi Etil Asetat Daun Kasturi (Mangifera casturi Koesterm), Skripsi Fakultas Matematika Dan Ilmu Pengetahuan Alam Universitas Lambung Mangkurat. Banjarbaru

17. Ghasemi, K., Ghasemi, Y., and Ebrahimzadeh M. 2009. Antioxidant Activity, Phenol and Flavonoid Contents of 13 Citrus Species Peels and Tissue, Vol. 22, No. 3, Pak. J. Pharm.Sci..277-281

18. Nan $\mathrm{Wu}$, et., al. 2009. Antioxidant Activity of Extracts and Main Components of Pigeonpea (Cajanus cajan (L.) Millsp.) Leaves. Article Molecules. 14. 1032-1043 